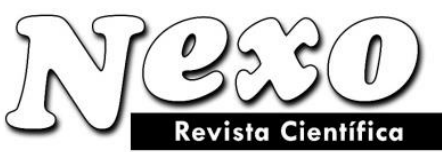

Vol. 34, No. 02, pp. 661-670/Junio 2021
ISSN-E 1995-9516

Universidad Nacional de Ingeniería COPYRIGHT (C) (UNI). TODOS LOS DERECHOS RESERVADOS http://revistas.uni.edu.ni/index.php/Nexo https://doi.org/10.5377/nexo.v34i02.11550

\title{
Seismic hazard and seismicity parameters in southwestern Alborz
}

\section{Peligro sísmico y parámetros de sismicidad en el suroeste de Alborz}

\author{
Fereshteh Pourmohammad ${ }^{1}$, Mehdi Zare*2, Arezoo Dorostian ${ }^{1}$, Bahram Akasheh $^{1}$ \\ ${ }^{1}$ Department of Geophysics, North Tehran Branch, Islamic Azad University, Tehran, Iran. \\ ${ }^{2}$ International Institute of Seismology and Earthquake Engineering, Tehran, Iran. \\ *mzare@iiees.ac.ir
}

(recibido/received: 03-enero-2021; aceptado/accepted: 14-abril-2021)

\begin{abstract}
Alborz Province is located west of Tehran Province on the South Alborz seismic belt. Geological and seismological analyses within a radius of $200 \mathrm{~km}$ from the center of Karaj identified five seismic zones and seven linear seismic sources. The maximum magnitude was calculated for the seismic zones using available correlations. The Kijko and Sellevoll (1992) method was used to calculate seismicity parameters, and the graphs of the return period and the probability frequency of recurrence of the earthquake magnitude in each zone were plotted for the 475-year return period. According to the calculations, the highest and lowest earthquake magnitudes of 7.6 and 6.2 were respectively obtained in Zones 1 and 4.
\end{abstract}

Keywords: Earthquake, Seismic zones, Magnitude, Return period

\section{RESUMEN}

La provincia de Alborz se encuentra al oeste de la provincia de Teherán en el cinturón sísmico del sur de Alborz. Los análisis geológicos y sismológicos dentro de un radio de $200 \mathrm{~km}$ desde el centro de Karaj identificaron cinco zonas sísmicas y siete fuentes sísmicas lineales. La magnitud máxima se calculó para las zonas sísmicas utilizando las correlaciones disponibles. Se utilizó el método de Kijko y Sellevoll (1992) para calcular los parámetros de sismicidad, y se trazaron las gráficas del período de retorno y la frecuencia de probabilidad de recurrencia de la magnitud del terremoto en cada zona para el período de retorno de 475 años. Según los cálculos, las magnitudes de terremoto más alta y más baja de 7,6 y 6,2 se obtuvieron respectivamente en las Zonas 1 y 4.

Palabras clave: Terremoto, Zonas sísmicas, Magnitud, Periodo de devolución

\section{INTRODUCCIÓN}

A significance of seismic studies is that the correct seismic analysis of any type (seismic hazard analysis, seismic risk analysis, ground seismic response analysis, seismic site effects, and structural dynamic analysis) can offer useful economic parameters and avoid conservative design and implementation, which lead to an irrational increase in project costs and poor implementation, which in turn causes increased risk and possibility of destruction. 
Alborz sedimentary-structural zone includes highlands north of Iranian Plate extending in an east-west direction from Azerbaijan to Khorasan in the form of a composite anticline. From a geomorphological point of view, the northern border of Alborz corresponds to hills consisting of Tertiary deposits and the Caspian coastal plain. From a geological point of view, the northern border of Alborz is bounded by the ancient Tethys geosuture formed by the collision of Alborz continental lithosphere and Turan lithosphere in the late Triassic Period. Most parts of the geosuture are, however, covered with plates moving from north to south. The southern bounds of Alborz are not very clear, and it seems there are no clear borders in southern Alborz, and a gradual transition had occurred from Central Iran to Alborz.

According to the seismotectonic map of Iran (Berberian 1976, Yazdi et al. $2019 \mathrm{a \& b}$ ), earthquakes in Alborz are shallow. There are also some intermediate earthquakes, and overall, the eastern Alborz is more earthquake prone than the western Alborz.

\section{GEOGRAPHICAL LOCATION}

Located in the south of Central Alborz highlands, Alborz Province is bounded by Mazandaran Province to the north, Markazi Province to the south, Tehran Province to the east, and Qazvin Province to the west. With an area of $5142 \mathrm{~km}^{2}$, it is located between the longitudes $50^{\circ} 10^{\prime}$ and $51^{\circ} 30^{\prime}$ and the latitudes $35^{\circ} 31$ and $36^{\circ} 21$. Alborz Province and its capital, Karaj, are located on the South Alborz seismic belt. The study area includes the eastern part of central Alborz in Tehran Province. Tectonically, it is part of the northern margin of the Iranian Plate. From the seismotectonic point of view, it is located on the seismic belt on the Iran-Turan convergent plate. Alborz Province is located in the east of this plate. The general direction of highlands in the region is east-west, along with some scattered reliefs. Baraghan River has created a deep valley with an east-west direction in the Alborz Mountains with nearly north-south branches. In the south of the plate, Shoor River flows from east to west after drainage from Eshtehard Desert. The river changes its direction from north to south and flows into Lake Houz Sultan after joining Sroud River. The province has a great diversity in terms of climate, with desert climate in the southern parts and semi-humid and humid climates in the northern parts.

\section{MAJOR FAULTS IN THE STUDY AREA}

A fault is a set of fractures in the Earth's crust that relative displacement occurs along their direction. The shear movement continues on both sides of the fault, from ground surface to large depths. Faulting and earthquakes occur due to the accumulation of stresses caused by the relative movements of tectonic plates and the movements within the upper mantle.

Most faults in Alborz follow the direction of existing folds with thrust mechanism and left lateral strikeslip. In this zone, the number of faults sloping towards the Caspian Sea is almost equal to those with an opposite slope. High-angle strike-slip faults are more inclined towards the Caspian Sea. The major faults in the northern areas of Alborz slope toward the south, and those in the southern part usually slope toward the north. Strike-slip faults adjacent to the Central Iran Plateau are usually limited to the southern part of Alborz. A small component of normal displacement is clearly seen on some strike-slip faults. From seismotectonic point of view, almost all of the faults studied in this mountain range are active. The major faults in the study area include North Tehran fault, Taleghan fault, Mahdasht fault, Eshtehard fault, Eyvanaki fault, Mosha fault, and Rey fault. The major faults within a radius of $200 \mathrm{~km}$ from the study site were examined (Fig. 1). 

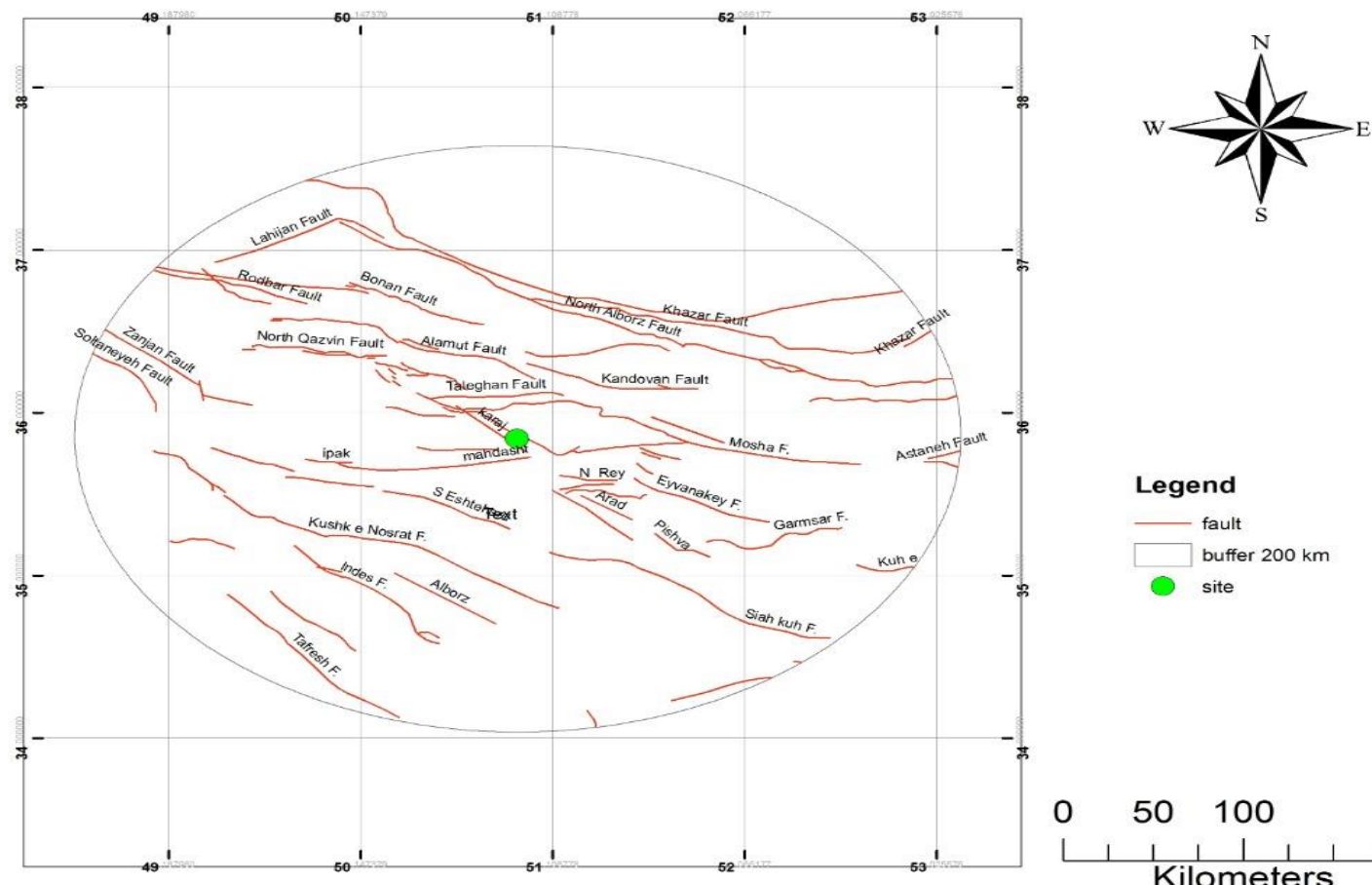

buffer $200 \mathrm{~km}$

site

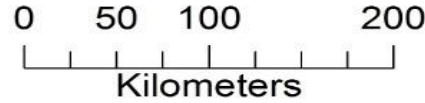

Figure 1. Major faults within a radius of $200 \mathrm{~km}$ from the study area.

\section{SEISMIC LAYER}

Determining the focal depth of earthquakes is essential for accurate interpretation of seismicity in regional tectonic studies and seismic hazard estimation. Despite the fact that existing global catalogs are used as sources of general information on focal depths, such catalogs are associated with a large error. Comparisons of focal depths by various seismological centers such as NEIC, ISC, and those calculated through teleseismic waveform inversion (Peristley et al., 1994; Maggie 2000) show that the error in the calculated depths reaches up to $60 \mathrm{~km}$. Therefore, it can be argued that such catalogs are not a suitable and accurate tool for determining the depth of seismic events in the study area.

Regardless of the modeling method for body waves, which can be used to accurately determine $( \pm 3 \mathrm{~km})$ the focal depth of earthquakes, the arrival times of seismic waves recorded in a dense and local seismological network offers the most appropriate method for determining the depth of earthquakes. The first method is mainly used for large earthquakes (often M> 5.5). Obviously, such a method can be applied to few earthquakes. Studies conducted in Iran using the teleseismic body wave modeling technique (Maggie et al. 2000 and 2002, Kheiri Namin et al. 2015, Nazemi et al. 2019, Baratian et al 2020) show that seismicity in the Iranian Plateau is essentially limited to the upper $20 \mathrm{~km}$ of the crust.

Nonetheless, it is necessary to determine the focal depth of all earthquakes in the study area to estimate the seismic hazard. To this end, a statistical study on the focal depth of the recorded earthquakes determines their distribution in the study area. Considering that most earthquakes reported in the study area have not been accurately relocated, they cannot be used to calculate the seismogenic layer. Hence, according to Maggi (2002), a depth of $15 \mathrm{~km}$ was considered the minimum depth for earthquakes occurring in the study area. 


\section{CALCULATION OF MAXIMUM MAGNITUDE (MMAX)}

The maximum magnitude $\left(\mathrm{M}_{\max }\right)$ is usually estimated based on the general characteristics of seismic activity and geological similarities. In applied studies, Mmax is often estimated based on correlation of seismic magnitude and different fault parameters such as rupture, fracture surface area, maximum surface displacement, and seismic moment release rate. Multiple correlations have been proposed to relate these parameters and the earthquakes magnitude. Table 1 shows some correlations by different scholars.

Table 1. Correlations between the earthquake magnitude and different fault parameters

\begin{tabular}{|c|l|c|}
\hline No. & \multicolumn{1}{|c|}{ Proposed by } & Correlation \\
\hline 1 & Mohajer and Nowroozi (1978) & Ms=5.4+LogLR \\
\hline 2 & Zare (1995) & Mw=3.66+0.91LnLR \\
\hline $\begin{array}{l}\text { Ms: Surface wave magnitude } \\
\text { Mw: Moment magnitude } \\
(\mathrm{km})\end{array}$ & $\begin{array}{c}\text { Lf: Fault length }(\mathrm{km}) \\
\text { L }_{\mathrm{R}} \text { : Rupture length }\end{array}$ \\
\hline
\end{tabular}

Correlations in Table 1 were used to calculate the maximum empirical magnitude, and the observed magnitudes for major faults in each zone were also reported (Table 2).

Table 2. Maximum empirical magnitudes calculated from correlations in Table 1 and the observed magnitudes

\begin{tabular}{|c|c|c|c|c|c|c|c|c|}
\hline \multirow[t]{3}{*}{ No. } & \multirow[t]{3}{*}{ Fault } & \multirow[t]{3}{*}{$\begin{array}{l}\text { Fault } \\
\text { Lengh }\end{array}$} & \multicolumn{2}{|l|}{ Zare (1995) } & \multicolumn{2}{|c|}{$\begin{array}{l}\text { Mohajer and } \\
\text { Nowroozi (1978) }\end{array}$} & Mmax & \multirow{3}{*}{$\begin{array}{l}\text { Observed } \\
\text { Magnitude }\end{array}$} \\
\hline & & & & & & & & \\
\hline & & & $\mathrm{LR}^{*} 0.37=\mathrm{Lf}$ & Mw & $\mathrm{L}=0.5 * \mathrm{Lf}$ & Mw & & \\
\hline 1 & $\begin{array}{l}\text { North } \\
\text { Tehran }\end{array}$ & 90 & 33.3 & 6.9 & 45 & 7.1 & 7 & 7.2 \\
\hline 2 & Mosha & 200 & 74 & 7.6 & 100 & 7.4 & 7.5 & 7.1 \\
\hline 3 & Abyek & 100 & 27 & 6.9 & 50 & 7.1 & 7 & 7.2 \\
\hline 4 & Taleghan & 64 & 13.68 & 6.5 & 32 & 6.9 & 6.7 & 5.3 \\
\hline 5 & Alamutrud & 100 & 37 & 6.9 & 50 & 7.1 & 7 & 7.6 \\
\hline 6 & Baijan & 45 & 16.65 & 6.2 & 22.5 & 6.8 & 6.5 & 7 \\
\hline 7 & $\begin{array}{l}\text { North } \\
\text { Eshtehard }\end{array}$ & 60 & 22.2 & 6.5 & 30 & 6.9 & 6.7 & 5.3 \\
\hline 8 & $\begin{array}{l}\text { South } \\
\text { Eshtehard } \\
\& \\
\text { Eshtehard }\end{array}$ & 80 & 29.6 & 6.7 & 40 & 7 & 6.85 & - \\
\hline 9 & Kandovan & 76 & 28.12 & 6.7 & 38 & 7 & 6.85 & - \\
\hline 10 & Lar & 25 & 9.25 & 5.7 & 12.5 & 6.5 & 6.1 & 4.5 \\
\hline 11 & Eyvanaki & 80 & 29.6 & 6.7 & 40 & 7 & 6.85 & 7.6 \\
\hline
\end{tabular}




\begin{tabular}{|c|l|c|c|c|c|c|c|c|}
\hline 12 & Kahrizak & 40 & 148 & 6.1 & 20 & 6.7 & 6.4 & - \\
\hline 13 & North Rey & 165 & 6.105 & 5.3 & 8.25 & 6.3 & 58 & 7.1 \\
\hline 14 & South Rey & 185 & 6.845 & 5.4 & 9.25 & 6.4 & 5.9 & 7.1 \\
\hline 15 & Garmsar & 70 & 25.9 & 6.6 & 35 & 6.9 & 6.75 & 5.4 \\
\hline 16 & Pishva & 34 & 12.58 & 6 & 17 & 6.6 & 6.3 & - \\
\hline 17 & $\begin{array}{l}\text { Robat } \\
\text { Karim }\end{array}$ & 90 & 33.3 & 6.9 & 45 & 7.1 & 7 & 4.9 \\
\hline
\end{tabular}

\section{POTENTIAL EARTHQUAKE SOURCES}

The analysis of earthquake hazard requires modeling of seismic sources. The earthquake source location is of great importance as the energy of waves decreases with distance. Different methods are available for earthquake source modeling taking into account the geological conditions. For instance, in some areas, the modeling of a seismic source involves an area where large earthquakes occur on the fault. Studies on seismic faults around the world show that the fault is not ruptured during a single earthquake, rather they break in the form of isolated pieces. In other words, fault zones are often divided into isolated parts. These parts are broken independently during different seismic events. The seismic depth is used to model the isolated sources. In the case of insufficient accuracy and inability to identify a fault as a seismic source in the seismic hazard analysis, the more conservative seismotectonic method can be used instead of active faults, in which the seismic sources are studied as wider seismic zone sources.

The concept of seismotectonics is practically used in the seismic hazard analysis for determining the seismotectonic source without any need for knowing or determining the exact details or location of seismic events. However, there are often problems in low-seismic areas, particularly in inter-plate areas where the tectonics theory is less useful in determining the seismotectonic sources. Considering the geological and seismological data, five seismic zones along with seven linear seismic sources were determined in the study area (Fig. 2).

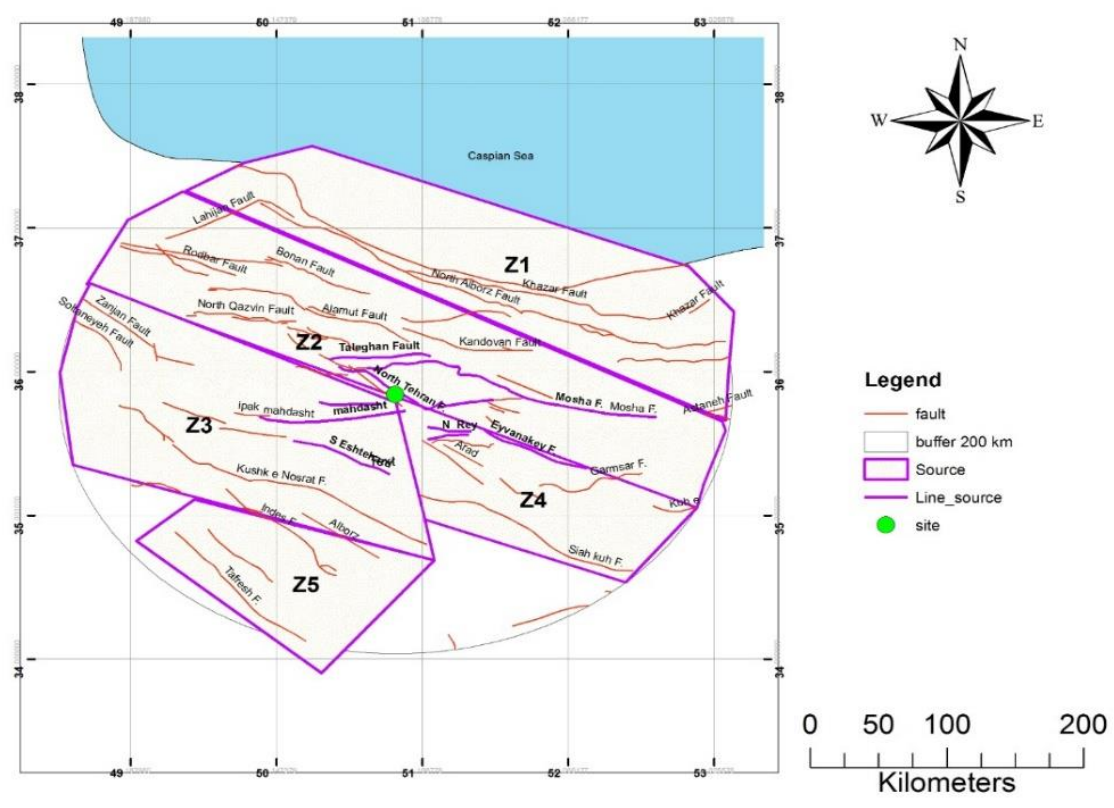

Figure 2. Seismic zones with linear seismic sources around the seismic site. 


\section{SEISMICITY PARAMETER ESTIMATION}

The K-S method was used to achieve seismicity parameters within the scope of this study. The methods presented by Kijko and Sellevoll (1992) allow the inclusion of the uncertainty of the earthquake magnitude and insufficient data in estimating the seismicity parameters. The results obtained from the analysis of seismicity parameters using the K-S method in seismic zones around the seismic site are presented in Table 3. These results were used to plot the graphs for return period and the probability frequency of recurrence of the earthquake magnitude in each zone for the 475 -year return period (Fig. 3 to 7).

Table 3. Seismicity parameters around the seismic site

\begin{tabular}{|c|c|c|c|c|c|}
\hline \multicolumn{2}{|l|}{ Zone } & \multicolumn{2}{l|}{$\begin{array}{l}\text { Beta } \\
\text { Lambda for Mmin }\end{array}$} & Mmax & \\
\hline z1 & 1.44 & \pm 0.15 & 1.932 & 7.6 & \pm 0.2 \\
\hline $\mathrm{z} 2$ & 1.69 & \pm 0.14 & 1.88 & 7 & \pm 0.2 \\
\hline $\mathrm{z3}$ & 1.74 & \pm 0.2 & 1.0108 & 7 & \pm 0.2 \\
\hline $\mathrm{z} 4$ & 1.71 & \pm 0.30 & 0.898 & 7.4 & \pm 0.2 \\
\hline z5 & 1.76 & \pm 0.30 & 1.048 & 6.7 & \pm 0.2 \\
\hline Mahdasht & 1.74 & \pm 0.22 & 0.246 & 7 & \pm 0.2 \\
\hline Taleghan & 1.69 & \pm 0.22 & 0.196 & 7 & \pm 0.2 \\
\hline North Tehran & 1.69 & \pm 0.22 & 0.276 & 7 & \pm 0.2 \\
\hline Rey & 1.71 & \pm 0.22 & 0.057 & 6.2 & \pm 0.2 \\
\hline Eyvanaki & 1.71 & \pm 0.22 & 0.246 & 7.4 & \pm 0.2 \\
\hline Mosha & 1.69 & \pm 0.22 & 0.614 & 7.4 & \pm 0.2 \\
\hline Eshtehard & 1.74 & \pm 0.22 & 0.246 & 7 & \pm 0.2 \\
\hline
\end{tabular}
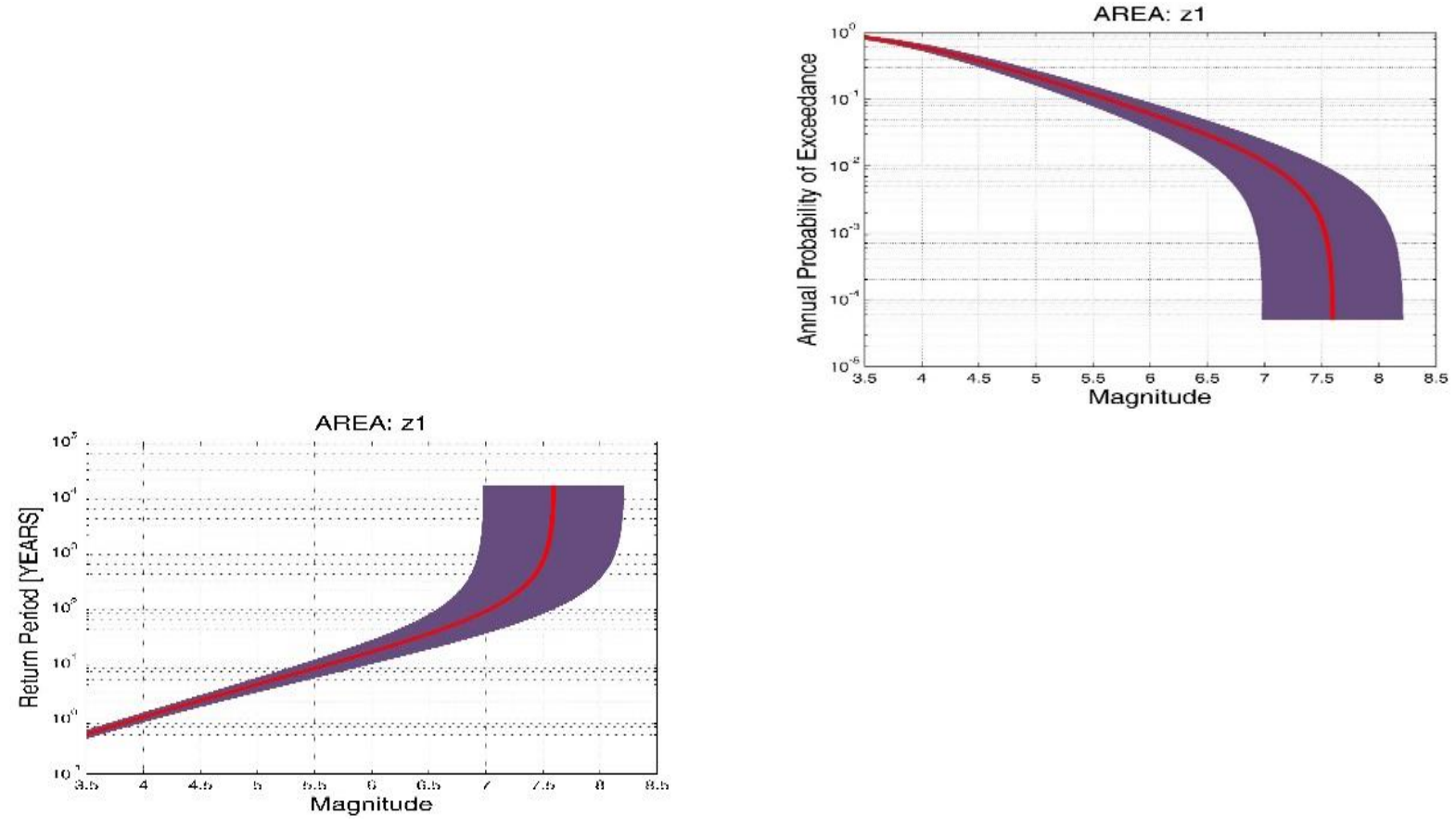

Figure 3. The frequency diagram and return period for Zone 1. 

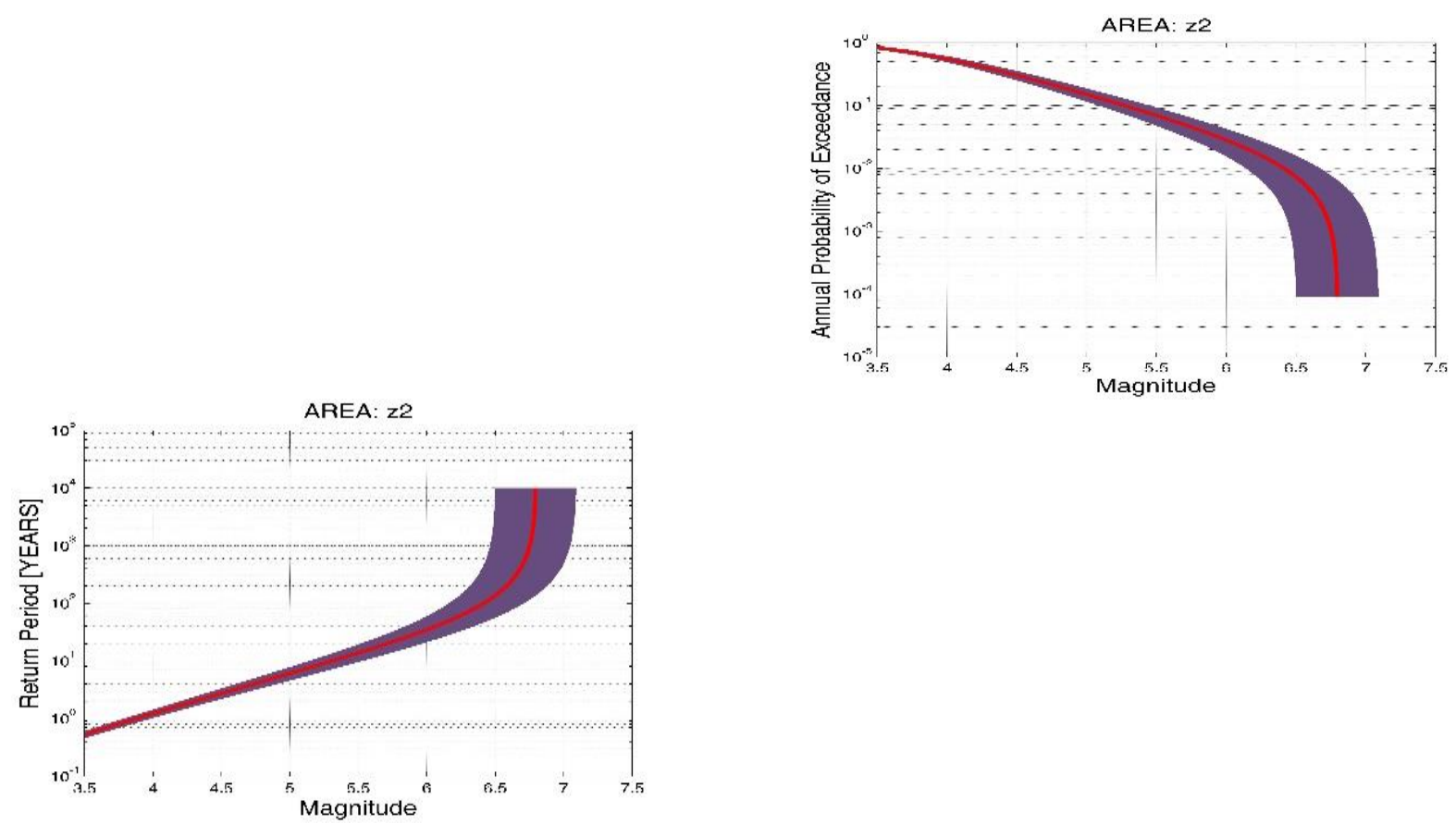

Figure 4. The frequency diagram and return period for Zone 2.
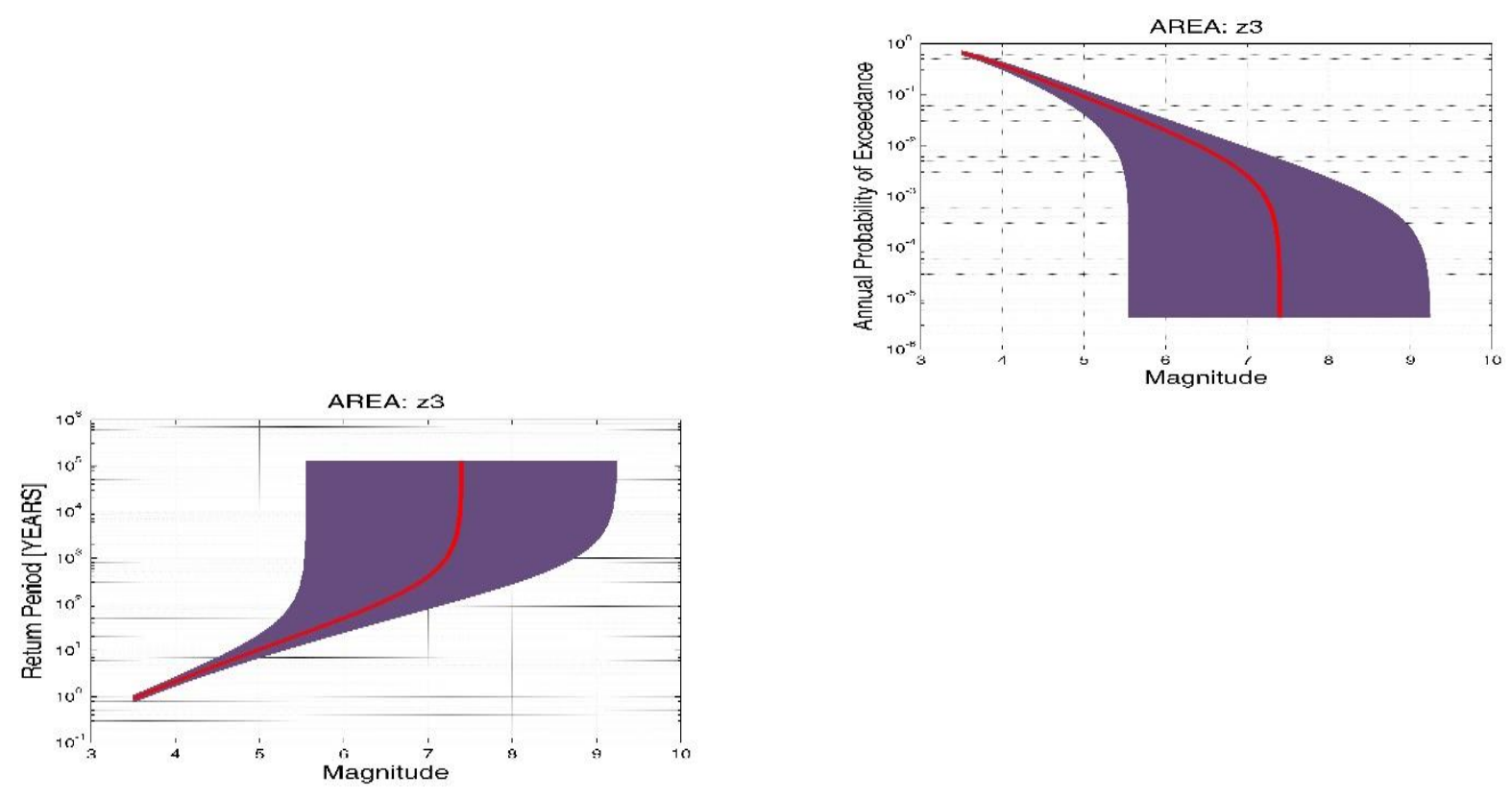

Figure 5. The frequency diagram and return period for Zone 3. 

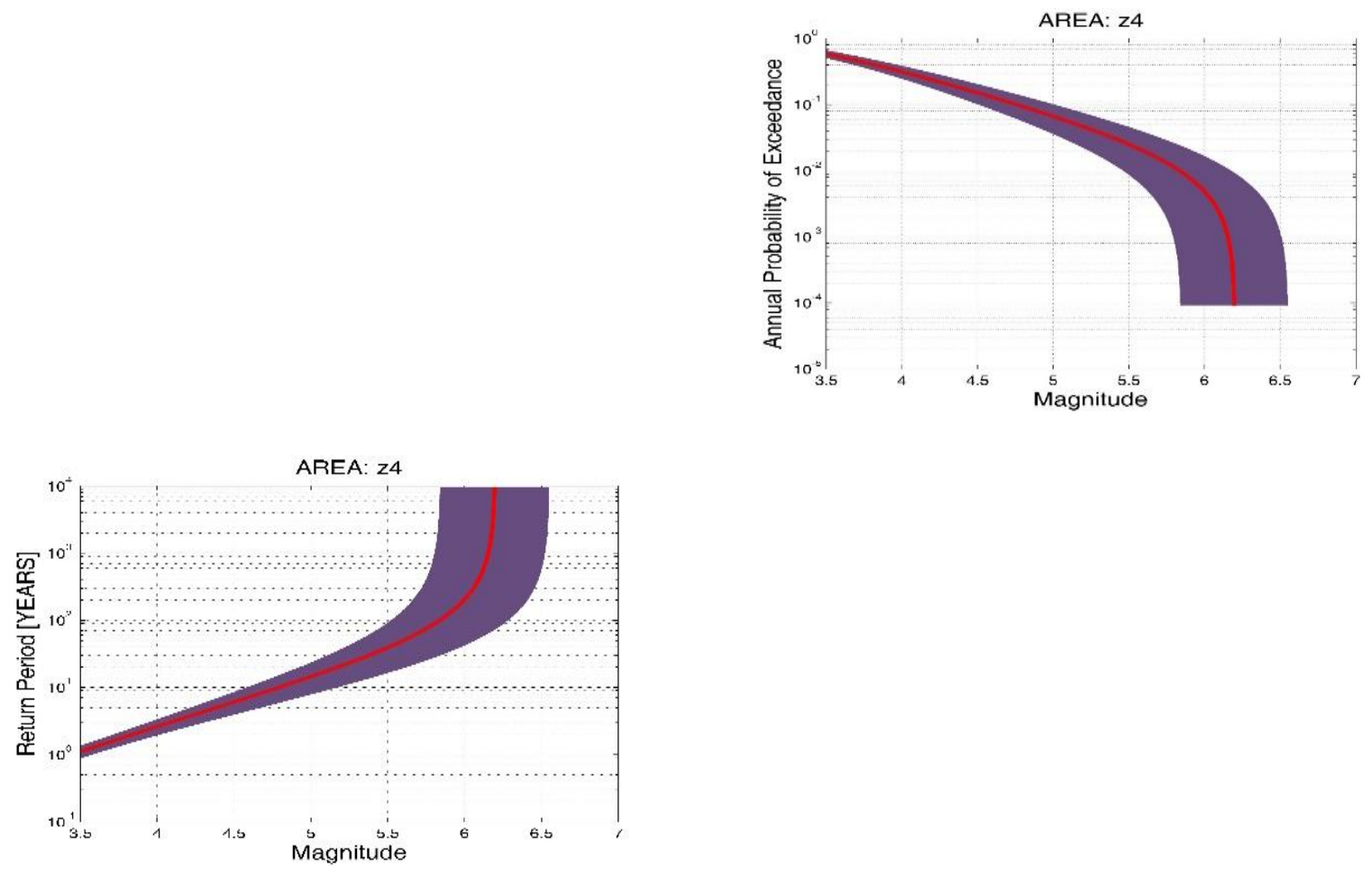

Figure 6. The frequency diagram and return period for Zone 4.
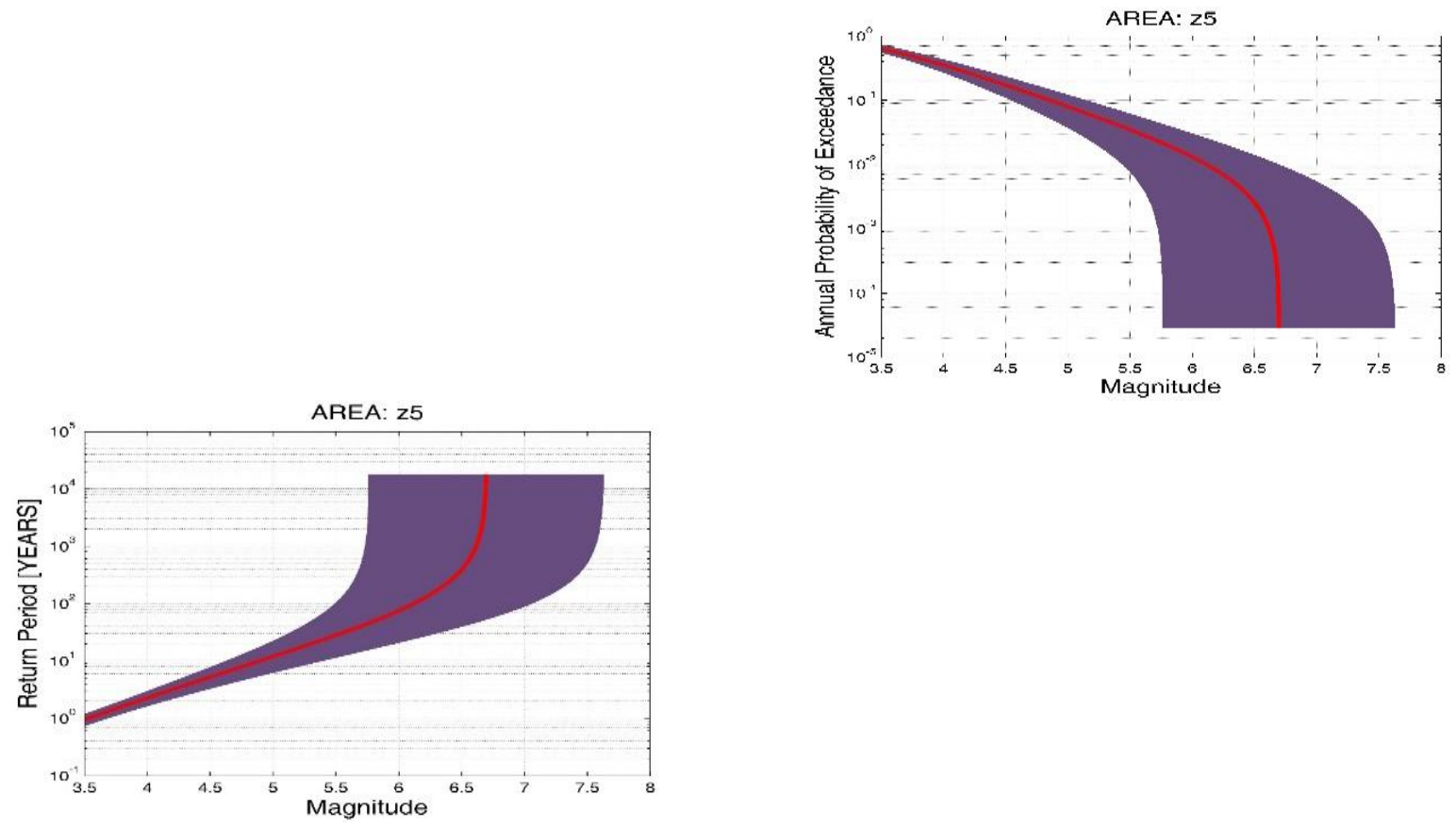

Figure 7. The frequency diagram and return period for Zone 5. 


\section{CONCLUSIONS}

The recent Malard Earthquake with a magnitude of 5.2 on the Richter scale and multiple earthquakes with magnitudes above 4 have increased the importance of seismic studies in the region. Seismic hazard studies are among the key preliminary urban development studies for preventing seismic vulnerability. The identification of seismic source zones is closely related to development infrastructure in any region. The results of these studies are widely used in vital projects such as water, gas, oil transmission lines, dam and airport construction, and residential development, and overlooking them may cause great damages. The earthquake hazard analysis based on the accurate location of seismic zones will provide more reliable results. The investigation of the region under study, its history of seismicity, and the recent earthquakes indicate the existence of seismic activity in the region. Considering the shallow depth of earthquakes, the intensity of earthquakes occurred in the region is high. Moreover, the calculation of $\beta$ and $\lambda$ parameters (ranging from 6.2 to 7.6) shows the seismicity of the region, indicating the need for observing safety measures in the constructions in the region. As mentioned earlier, the recent seismic activities and earthquakes in the region have doubled the importance of seismic studies and measures for strengthening seismic stations in the region. Moreover, the review of seismic catalogs show that the study area has been inactive over the past few decades and hence its sudden activity is quite significant.

\section{REFERENCES}

Baratian, M., Arian, M.A., \& Yazdi, A. (2020). Petrology and Petrogenesis of Siah Kooh volcanic rocks in the eastern Alborz. GeoSaberes, v . 11, p. 349-363. DOI: https://doi.org/10.26895/geosaberes.v11i0.980

Berberian, M. (1976). Contribution to the Seismotectonics of Iran, Geological Survey \& Mineral Exploration of Iran.

Berberian, M., Qoreishi M., Talebian M., Shoja Taheri, J. (1996). Investigation of Neotectonics and Earthquake Faulting Hazard across Semnan, Geological Survey \& Mineral Exploration of Iran.

Kheiri Namin, O., Ashja Ardalan. A., Razavi. M.H., Gourabjeripour. A., \& Yazdi. A. (2015). Mineral Chemistry Studies and Evidences For Magma Mixing of Bala Zard Basic- Intermediate Volcanic Rocks, Lut Block, Iran. Current World Environment, 10(S, May): 1194-1205. DOI: http://dx.doi.org/10.12944/CWE.10.Special-Issue1.140

Maggi, A. (2002). Focal Depths of Moderate and Large Size Earthquakes in Iran, Journal of Seismology and Earthquake Engineering, Vol. 4.No. $2 \& 3$.

Nazemi, E., Arian, M.A., Jafarian, A., Pourkermani, M., Yazdi, A. (2019). Studying The Genesis Of Igneous Rocks In Zarin-Kamar Region (Shahrood, Northeastern Iran) By Rare Earth Elements, Revista Gênero e Direito, 8 (4), 446466.

Nowroozi, A.A., and Mohajer-Ashjai, A. (1985). Fault movements and tectonics of Eastern Iran: boundaries of the Lut plate. Geophysical Journal International. 83(1) 215-237, DOI: https://doi.org/10.1111/j.1365246X.1985.tb05164.x

Yazdi, A., Ashja-Ardalan, A., Emami, M.H., Dabiri, R., \& Foudazi, M. (2019-a). Magmatic interactions as recorded in plagioclase phenocrysts of quaternary volcanics in SE Bam (SE Iran). Iranian Journal of Earth Sciences, 11(3): 215-224. 
Yazdi, A., Shahhosini, E., Dabiri, R., Abedzadeh, H. (2019-b) Magmatic differentiation evidences and source characteristics using mineral chemistry in the Torud intrusion (Northern Iran), Revista Geoaraguaia, 9 (2).

Zare, M. (1995). Relationships of Magnitude, Intensity and Peak Horizontal Acceleration Based on Earthquakes in Iran, Journal of Seismology and Earthquake Engineering. 